\title{
製造現場における間接作業平準化のための スケジューリングアルゴリズムに関する研究*
}

\author{
則 竹茂 年*1, 富 永孝*2
}

\section{The Study on Scheduling Algorithm for Indirect Work Balancing in Manufacturing Systems}

\author{
Shigetoshi NORITAKE*3 and Takashi TOMINAGA \\ *33 Toyota Central R \& D Labs., Inc., \\ Nagakute, Nagakute-cho, Aichi-gun, Aichi, 480-1192 Japan
}

\begin{abstract}
Manufacturing systems usually have some indirect works needed at various cycles. In indirect works, the tool exchange, maintenance, the quality check, the part replenishment, etc. are included. In order to operate the manufacturing system efficiently, it is effective way to make a schedule in consideration of the work load balancing and to operate them without error using work-order cards. We have developed the scheduling algorithm to output appropriate work balance with easiness and steady by taking a heuristics in that longer time task have more influence to the work balance degree. This paper discribes the study on the algorithm. In addition, this paper discusses the algorithm that is able to find the meta-parameters values to output the minimum cost schedule.
\end{abstract}

Key Words: Scheduling System, Work Load Balancing, Indirect Work, Manufactuting System

\section{1.はじめに}

生産システムを正常に運用するためには, 日常保全 や部品補充，品質チェック，工具交換などの間接的な 作業を適切なタイミングで行う必要がある. 各間接作 業は独自の周期で実施されるため, いくつかの間接作 業の実施が一時に集中する場合がある。その際に発生 する対応遅れによる生産システムへの悪影響を最小限 に留めるため, 作業負荷がピークになる時の工数を考 慮して作業者数を決めることになる，そのことは，市 場競争下における生産システムの原価低減を妨げる一 因となっている。

著者らは, 生産順序が平準化されている生産システ ムにおいて間接作業に関する必要作業員数の最少化, および，作業の安定供給を狙い，間接作業を平準化し たスケジューリング方式(本論では「間接作業平準化 方式」と呼ぶ）を導入した，本方式では，あらかじめ， 間接作業を一定の生産量ごとに行うように配分してお き，その決められた生産量をトリガーに作業内容を指

* 原稿受付 2007 年 3 月 29 日.

*1 正員, (株) 豊田中央研究所数理情報研究室 (画 480-1192 愛 知県愛知郡長久手町長湫).

*2 (株) 豊田中央研究所数理情報研究室.

E-mail : noritake@ mosk.tytlabs.co.jp
示することで，安定的に間接作業を実施する。ここで， 一定の生産量ごとに作業者へ作業指示するために, 作 業者が 1 回に行う間接作業項目を記載したカードのこ とを, 本論では「作業指示書」と表現する，また，本 論で述べる「作業」はすべて間接作業のことを表す。 なお，本論では，作業の平準化において，同じレベル の品質を確保するため工程ごとの品質チェック周期や 工具ごとの交換間隔を加工進捗に合わせて一定に保 ち, さらに, 部品置き場のスペースを節約するため部 品ごとの補充間隔も加工進捗に合わせて一定に保って いる生産システムを対象としている。すなわち, 各作 業の間隔を一定加工数に合わせることを制約としてい る生産システムを対象に最適な間接作業スケジューリ ングを提供することを狙いとしている．各作業を工具 寿命や部品棚最大容量に起因する限界間隔より短く, 一定間隔になるように調整するため, 過剰作業となる が，作業平準による余剩人員削減のメリットのほうが 大きいと考えられることが多い.

間接作業平準化方式の運用に際し, 多数ある作業を 平準化したスケジュールを作成することはかなり手間 がかかる．現状，経験豊富な現場担当者が 1 日がかり で作成しており，作成したスケジュールの良否も評価 できていない.さらに，多品種の製品を扱う混流ライ 
ンに扔いては，製品種別に特化した専用工具の交換作 業や專用部品の補充，品質チエック作業などの必要頻 度が生産比率に応じて変化するため, 頻繁に発生する 生産比率変更のたびに平準化スケジュールを最初から 作成し直さなければならない。 また，工具寿命の延命 や品質チェック作業の見直し(簡易化)などのカイゼン 活動により, 条件が変化した場合も再スケジューリン グが必要となる.

そこで, 著者らは, 即座に再スケジューリングする ことを可能とした作業負荷の自動平準化スケジューリ ングシステムを開発した。具体的には，工場で定型的 に作成している間接作業用リストや工具データシート （工具情報リスト）を読み込み，作業の分割数を意味す る作業指示書枚数や，作業指示書 1 枚当たりの処理と 同期させる生産個数(以降，「基準加工数」とする)等 の条件を設定し, 数分で平準化スケジュールを作成し, 作業指示畫として出力できるようにした. その際, 作 業時間が長い作業ほど全体の平準化度合への影響が大 きいことを考慮したヒューリスティックスを取り入れ ることで, 試行しながら利用するユーザが許容できる 時間(数分)で, 優良なスケジュールを安定的に出力す ることを可能とした.

本論では, 2 章と 3 章で, 本論の主題である平準化 スケジューリングの前提条件と定式化, および, 具体 的なスケジューリングアルゴリズムについて説明す る.

さらに，著者らが初心者への普及を想定した補足機 能として, 間接作業の実施頻度に応じた費用 (工具費 等)を考慮した作業コスト最小化のためのメ夕条件, すなわち, 適切な作業指示書枚数と基準加工数を自動 で見つけるアルゴリズムを開発したので，4 章と 5 章 で説明する。そして，6 章で簡単な実験例を示し，7章 でまとめる.

\section{2. 平準化スケジューリングの 前提条件と定式化}

従来, 報告されている生産分野におけるスケジュー リング研究は生産 (加工) 順序スケジュールを対象とし ている報告例が多く(1)(2), 本問題のような生産スケジ ユールを既与として, 保全作業等の間接作業を対象と している報告例は多くない。例えば，工具寿命を統計 量として，その最適交換時期を論じている報告例(3)(4) はあるが, 間接作業全体の負荷の平準化を主題とする 本研究とは視点が異なる。また，他分野ではあるが類 似の定式化が可能な研究事例として, ナース・スケジ ューリング問題(5)(6) や, 鉄道の乗務員割当て問題(7),
学校時間割自動編成 ${ }^{(8)}$ などが報告されているが，これ らの手法は対象依存性が強く, 制約条件や考慮ルール が異なる本問題へ利用することは困難である．特に， 著者らは実用化に重きをおいているため, 実用的な時 間内で，ある程度良い解を安定的に発見でき，かつ， ユーザに理解しやすい簡単なアルゴリズムであること を重視した。

そこで, 本問題に合わせて, 独自に定式化すること を試みた。その際, 各作業要素の 1 回当たりの作業時 間は事前測定や経験値によってあらかじめ確定されて いるとする.また, 移動時間については, 各作業指示 書に,さまざまな工程の間接作業が満遍なく割当てら れることが多く，すべての作業指示書で歩行時間の合 計が均一化することが期待できるため, 無視できると した。

ここで, 基準加工数はトラブル停止の影響を排除し た生産の進捗に同期させるべく，時間ではなく特定設 備での加工数とした. 特に, 中間在庫が多くなく設備 間の進捗度合の差を一定数以下に抑えられる場合, あ る特定の設備の加工進捗のみをチェックすることで, 生産システム内の全設備の進捗とほぼ同期することに なる.また, 各作業を必要な作業間隔以内で, かつ, 作業要素ごとに等間隔することを制約条件とすること は, 製品の品質レベルを均一にし, 品質管理を容易に するという現場からの強い要望であり, 本システムで も採用した。これに関連し，すべての作業指示書を実 行した後に1枚目の作業指示書に戻って繰返すため, 全作業指示書を一巡するたびに，半端な作業間隔とな る作業要素が発生しないように, 各作業は, “基準加 工数” $\times$ “作業指示書枚数の約数” の間隔で行うこと とする. 例えば, 基準加工数 1000 , 作業指示書の枚数 が 30 枚の場合, 30 の約数は $1,2,3,5,6,10,15,30$ であるため, 各作業は監視設備での加工数が 1000 , $2000,3000,5000,6000,10000,15000,30000$ のい ずれかの間隔で行うことになる，そのため, 例えば, 9000 回加工できる工具を 6000 回で交換することに なり, 使用する工具本数 (工具費)が 1.5 倍になる.こ のことは, コスト面では大きな損失となり, 人件費削 減効果とのトレードオフがしばしば議論される.

そこで, 約数を多くもち, かつ, 対象とする作業の 必要作業間隔との差異の総和を小さくする約数を多く もつ值を作業指示書枚数として選択することで，コス トのむだを最小限に抑え, 本システムによる作業工数 の削減や品質均一化の利点を相対的に大きくすること が望まれる.この作業指示書枚数の設定については, 作業指示書と作業量の管理上, 作業指示書枚数が多す 
ぎることなく，かつ，作業指示書 1 枚当たりの作業時 間も過剩に長くならないように許容範囲を設定した。

一方, 必要作業間隔が同じぐらいで, かつ, 同一機 械，同一内容のセッティングを伴う作業要素の組があ る場合, それらを一つの作業としてまとめることで, 作業工数が削減し, 生産システムへの影響を小さくで きる場合がある。そこで, 特定の条件を満たした作業 要素は同時に作業するという制約を設けた。

以上のことを踏まえ, 各作業指示書に割付けられる 作業時間の合計を求め, その均一度合を表す目的関数 を決めた。以下に定式化について説明する。

最初に, 作業ごとにその許容する最大作業間隔を求 める.その際, 複数種類を生産する混流ラインの場合 はその生産比率を反映した値にする，例えば, 対象 インにおいて，1/3の割合で生産(加工)する品種のみ に対する専用部品棚への補給作業や, 品質チェック作 業, 専用工具の交換作業に関しては, 本来の部品補給 間隔や品質チェック間隔, 工具寿命を 3 倍にした值を 最大作業間隔とする.

次に, 作業指示書枚数を $N$ とし, 全作業要素数を $W$, 任意の作業要素 $k$ の作業時間を $t_{k}$ とした場合, 作業要素 $k$ の最大作業間隔を基準加工数で割った值 以下で, $N$ の約数の最大値 $M_{k}$ を求める. すなわち, 作業要素 $k$ は全 $N$ 枚の作業指示書中, $M_{k}$ 枚ごとに 1 回，等間隔で作業指示されることになる。よって，作 業要素 $k$ の作業時間 $t_{k}$ を作業指示書の $i(i=1 \sim N)$ 番めへ割当てた場合を $t_{k i}$ とし, 実際に作業要素 $k$ を 最初に割当てた指示畫番号を $p_{k}\left(\leqq M_{k}\right)$ 番目とする ¿,

$$
t_{k i}=\left\{\begin{array}{cc}
t_{k} \quad\left(\text { if } i=p_{k}, p_{k}+M_{k}, p_{k}+2 M_{k}, \cdots,\right. \\
\left.\quad p_{k}+N-M_{k}\right) \\
0 \quad \text { (others) }
\end{array}\right.
$$

となる。次に, 各作業指示書に記載されている作業時 間の総和を $T_{i}$ として,

$$
T_{i}=\sum_{k=1}^{W} t_{k i}
$$

を求める. 本研究の目的は各作業指示書へ割当てられ た作業時間の合計が，すべて作業指示書で均一になる ことである.そこで, 目的関数 $G$ として,$i=1 \sim N$ において, 各 $T_{i}$ の分散を小さくするための関数,

$$
G=\min \left\{\sum_{i=1}^{N}\left[T_{i}-\frac{1}{N}\left(\sum_{i=1}^{N} T_{i}\right)\right]^{2}\right\}
$$

を定義した。すなうち, 本研究で行う平準化スケジュ 一ル問題を $k=1 \sim W に$ におる $p_{k}$ を制御変数とし, 式 ( 3 )を目的関数とした最小化問題とした.

\section{3. 作業平準化アルゴリズム}

平準化スケジュールを作成する問題は，一般的に， 作業要素数に応じて解の候補数が指数的に增大する $\mathrm{NP}$ 困難な問題であるため, 実時間内で最適解, もし くは準最適解を見つけるには, 効率的な最適化アルゴ リズムの援用が必要となる。例えば，分岐限定法やダ イナミック・プログラミング, ラグランジュ緩和法な どのような数理計画法や, 山登り法や最急勾配法など の逐次探索法, シミュレーテッド・アニーリング法や タブサーチ法, 遺伝的アルゴリズムのようなメタヒュ ーリスティクス探索法などがある(2). しかしながら， 分岐限定法やダイナミック・プログラミングでは組合 せ爆発から逃れることはできず，ラグランジュ緩和法 を適用できるような定式化は困難である，また，本問 題は作業時間が比較的長い作業要素の作業指示書への 割付先 $\left(p_{k}\right)$ の変更による目的関数 $(G)$ への影響が大 きいため, 作業時間が長い作業要素の割合によっては 超多峰な解空間を有する問題となり, 逐次探索手法で は得られる解の良否が初期解に大きく依存することが 想定される. 同様に,メタヒューリスティクス探索法 に执いても最適化度合と収束時間が安定しないことが 容易に予想される。

著者らは, 一般の工場管理者や計画者への普及のた め, 実運用上, ユーザの許容時間以内に一定レベル以 上の解に収束し, さらに, 解の収束過程についてユ一 ザが理解しやすいことを必要要件としたため, 本問題 においては, 上述の最適化アルゴリズムの適用は不適 切だと判断した。

そこで, 著者らは, 最適解を見つけることよりも準 最適な解を安定して見つけることを優先し, 作業時間 の長い作業要素から順に $p_{k}$ 值を決めていくヒューリ スティックスを取り入れることで探索空間を限定し, NP 困難ではない解空間上で, 可能な局所的組合せを 全探索して $p_{k}$ 值を決めていくことで, 準最適解を見 つけるアルゴリズムを採用した．全体スケジュールへ の影響が大きいと思われる作業要素から優先的に探索 することで, さまざまな作業要素の入れ替りに頑健な 結果を得ることができる.

具体的には, 下記の処理手順で平準化を行う.

Step 1：いっしょに作業を行う作業要素をグループ化 し, Step 2 以降, 一つの作業要素として扱う.

Step 2 : 全作業要素をその作業時間が長い順にソート

し, 1 から順にナンバリングする $\left(t_{1} \geqq t_{2} \geqq t_{3} \geqq \cdots\right.$ $\geqq t_{k} \geqq \cdots \geqq t_{W}$ となる).

Step 3: 各作業要素 $k$ に対し, 割当てる作業指示書間 
隔 $M_{k}$ を求める ( 2 章参照).

Step 4 : 作業要素 $(k=1)$ の割当指示書番号を $1\left(p_{1}=\right.$

1) とし, 式 ( 1 )により, $t_{1 i}(i=1 \sim N)$ を更新する.

Step 5:k=k+1とし, $p_{k} に 1$ から $M_{k}$ を順に代入

し, 式( 1 )により $t_{k i}(i=1 \sim N)$ の值を更新後, 式

(2) と式 $(3)$ より目的関数 $G$ が最小となる $p_{k}$ を 求める.

Step 6: 全作業要素の $p_{k}$ が決まるまで, Step 5 を繰 返す。

Step 7 : 各 $i(=1 \sim N)$ ごとに, $t_{k i}$ が正となる作業要

素 $k$ を工程順にソートして指示書番号 $i$ へ書き

出す(グループ化した作業要素は分解して記述す る).

以上のアルゴリズムにより，つねに，優良な作業平 準化スケジュール結果を出力できるようにした。

\section{4. 平準化条件の設定}

3 章の平準化アルゴリズムにより安定した結果を得 ることができるため，作成するスケジュールの良し亜 しは, 指定する作業指示書枚数や基準加工数に大きく 依存する.そのため, 作業指示書枚数と基準加工数を 適切な値に決めることが重要となる。その際, 重要な 評価指標の一つに費用損失がある. 特に, 工具交換作
業や検査試験加工などに扔ける交換品や (人件費換算) 工数のように, 作業回数が費用変化に直接影響する対 象の場合, 作業回数の削減が重要な指標となる.

そこで, 費用損失を評価指標として, 作業指示書枚 数と基準加工数を決めるアルゴリズムを追加検討し た。以降, 説明をわかりやすくするため, 工具費を例 に説明する.

工具費の増加(損失分) は, 工具交換作業をその工具 寿命ではなく，作業指示書の実行タイミングに合うよ う等間隔で行うことが原因で発生する。例えば, 基準 加工数 1000 において 7000 回加工可能な工具を使っ た場合，作業指示書を 60 枚とすると $7000 / 1000$ 以下 で 60 の約数が 6 であることから，6000回 $(1000 \times 6)$ ごとに工具交換することとなる，また，作業指示書を 100 枚とすると同様に 5000 回 $(1000 \times 5)$ ごとに工具 交換することとなる。これらは，本来の工具寿命をき ちんと使い切る場合と比べ, 前者が工具費 $7 / 6$ 倍, 後 者が工具費 $7 / 5$ 倍となる.

費用損失分を最小にするには全工具の寿命の最小公 倍数を基準加工数で割った值を作業指示書枚数とすれ ばよいが, 工具寿命が都合良く揃うことはなく, 通常, 作業指示書枚数が膨大になり管理ができなくなる．表 1 は, 作業指示書枚数の違いによる単位加工製品当た

Table 1 Some examples of the number of card and cost

(a) An example of the case that standard interval is 1000 with 7 cards

\begin{tabular}{|c|r|r|r|r|r|r|r|}
\hline No. & $\begin{array}{c}\text { Tool Cost } \\
\text { (yen) }\end{array}$ & Tool Life & $\begin{array}{r}\text { Available } \\
\text { Tool Life }\end{array}$ & $\begin{array}{c}\text { Waste } \\
\text { Tool Life }\end{array}$ & Usage Ratio & $\begin{array}{r}\text { Tool Cost / 1000 } \\
\text { Products }\end{array}$ & $\begin{array}{c}\text { Loss Cost / } \\
\text { 1000 Products }\end{array}$ \\
\hline 1 & 6000 & 2100 & 1000 & 1100 & $48 \%$ & 6000 & 3143 \\
2 & 4000 & 3500 & 1000 & 2500 & $29 \%$ & 4000 & 2857 \\
3 & 2500 & 4000 & 1000 & 3000 & $25 \%$ & 2500 & 1875 \\
4 & 1000 & 5000 & 1000 & 4000 & $20 \%$ & 1000 & 800 \\
5 & 4500 & 3000 & 1000 & 2000 & $33 \%$ & 4500 & 3000 \\
\hline \multicolumn{1}{|r}{} \\
\hline
\end{tabular}

(b) An example of the case that standard interval is 100 with 46200 cards

\begin{tabular}{|c|r|r|r|r|r|r|r|}
\hline No. & $\begin{array}{c}\text { Tool Cost } \\
\text { (ven) }\end{array}$ & Tool Life & $\begin{array}{c}\text { Available } \\
\text { Tool Life }\end{array}$ & $\begin{array}{r}\text { Waste } \\
\text { Tool Life }\end{array}$ & Usage Ratio & $\begin{array}{c}\text { Tool Cost / 1000 } \\
\text { Products }\end{array}$ & $\begin{array}{c}\text { Loss Cost / } \\
\text { 1000 Products }\end{array}$ \\
\hline 1 & 6000 & 2100 & 2100 & 0 & $100 \%$ & 2857 & 0 \\
2 & 4000 & 3500 & 3500 & 0 & $100 \%$ & 1143 & 0 \\
3 & 2500 & 4000 & 4000 & 0 & $100 \%$ & 625 & 0 \\
4 & 1000 & 5000 & 5000 & 0 & $100 \%$ & 200 & 0 \\
5 & 4500 & 3000 & 3000 & 0 & $100 \%$ & 1500 & 0 \\
\hline \multicolumn{7}{|c|}{} \\
\hline
\end{tabular}

(c) An example of the case that standard interval is 1000 with 60 cards

\begin{tabular}{|c|r|r|r|r|r|r|r|}
\hline No. & $\begin{array}{c}\text { Tool Cost } \\
\text { (yen) }\end{array}$ & Tool Life & $\begin{array}{c}\text { Available } \\
\text { Tool Life }\end{array}$ & $\begin{array}{c}\text { Waste } \\
\text { Tool Life }\end{array}$ & Usage Ratio & $\begin{array}{r}\text { Tool Cost / 1000 } \\
\text { Products }\end{array}$ & $\begin{array}{c}\text { Loss Cost / } \\
\text { 1000 Products }\end{array}$ \\
\hline 1 & 6000 & 2100 & 2000 & 100 & $95 \%$ & 3000 & 143 \\
2 & 4000 & 3500 & 3000 & 500 & $86 \%$ & 1333 & 190 \\
3 & 2500 & 4000 & 4000 & 0 & $100 \%$ & 625 & 0 \\
4 & 1000 & 5000 & 5000 & 0 & $100 \%$ & 200 & 0 \\
5 & 4500 & 3000 & 3000 & 0 & $100 \%$ & 1500 & 0 \\
\hline \multicolumn{1}{|c|}{} \\
\hline
\end{tabular}


りの工具費用と工具ロス費の変化を少数の刃具を例に 計算した結果である。表 1(a)のように, 作業指示書 枚数を最小限にすると工具口ス費が大きくなり, 表 1(b)のように工具口ス費を零になるように作業指示 書枚数を設定しようとすると, 管理が困難な枚数 (46 200 枚)になる. 表 1 ( c ) は作業指示書枚数を多す ぎず，工具ロス費も小さく抑えた結果となっている. 例えば月産 1 万台の製品における 1 箇月の工具費は, 表1( a )〜 ( c )でそれぞれ180000円，63250円， 66580 円となり, 表 1 に示す少数工具の例においても 工具費の差が 3 倍程度になる。

以上の例のように, 費用の増加を少しでも減らすた めには, 基準加工数と作業指示書枚数を適切な値に設 定しなければならない.しかしながら,一つの生産シ ステムにはさまざまな寿命の工具が多数含まれ, さら に, 作業頻度が生産比率により変化するため, 適切な 条件を想起することが難しい. そこで, 工場での適用 を容易にするため, 基準加工数と作業指示書枚数を適 度な値に設定するアルゴリズムを追加開発した。

\section{5. 平準化条件の調整アルゴリズム}

以下に, 著者らが用いた基準加工数と作業指示書枚 数の決定方法を説明する。なお, 以下の説明では, 各 作業要素 $i$ の必要作業間隔(例：工具寿命, 部品棚容 量)を $F_{i}$ とし, 1 回の作業に必要な費用(例：工具 1 本の費用)を $C_{i}$ とする。 また, $[x]$ は $x$ 以下の最大整 数値とする.

Step 1 : 全作業要素から最小の必要作業間隔 $F_{i}$ をも つ作業を選択し，その作業間隔を $A$ とする $[A=$ $\left.\operatorname{Min}\left(F_{i}\right)\right]$.

Step $2: 1$ けたの自然数 $a$ と, 非負の整数値 $b$ に対し, $A \geqq a \times 10^{b}$ を満たす最大の $a$ と $b$ を求める.

Step $3: 1$ 以上 $a$ 以下の全自然数 $a^{*}$ による $a^{*} \times 10^{b}$ を基準加工数の候補値集合 $\left\{S^{*}\right\}$ とする.

Step $4:$ Step 3 で求めた, 候補値集合 $\left\{S^{*}\right\}$ に含まれ るすべての候補值 $s^{*}$ に対し, 以下の式より, 作 業指示書 1 枚当たりの理想平均作業時間 $T^{*}$ を求 め.

$T^{*}=\sum\left(T_{i} \div\left[F_{i} / s^{*}\right]\right)$

Step $5:$ Step 4 で求めた $T^{*}$ の中で, あらかじめ決め られた時間制約内に収まる $T^{*}$ をる候補值 $s^{*}$ を最終的な基準加工数 $S^{d e c}$ とする.ここで， $T^{*}$ に関する時間制約は，むだな歩行時間の比率が大 きくならないこと，および，作業指示の実施時間 における設備稼働率低下と休憩時間への影響を配 慮して, 経験的に決めた条件である。また， $T^{*}$

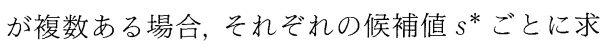
めた

Loss $=\sum\left\{\left(F_{i}-\left[F_{i} / s^{*}\right]\right) \times C_{i}\right\}$

が最も小さくなる $s^{*}$ を最終基準加工数 $S^{d e c}$ とす る.

なお, Step 5 において, 時間制約を満たす $s$ *がな い場合は, 設計者へ $\operatorname{Min}\left(F_{i}\right)$ と $\operatorname{Max}\left(F_{i}\right)$, 総作業時 間等の情報とともに適切な解がない旨を提示し, 作業 指示書で扱う作業内容の範囲変更や条件変更を促す.

一般的に, $T^{*}$ が小さすぎる場合, 総作業時間(作業要 素)が少なすぎるか, 過度に短間隔の作業が含まれて いることが原因であることが多い，また，T*が大き すぎる場合, 総作業時間(作業要素)が多すぎるか, 最 小間隔とほぼ同じ間隔の作業が多く含まれていること が原因であることが多い.上記の条件変更を適切な基 準加工数 $S^{\text {dec }}$ が決まるまで繰返す.

以上の Step 1〜 5 により, 半自動的に基準加工数を 決定する。

次に, 作業指示書枚数を決定する. 作業指示書枚数 に関しては, 管理上, 120 枚を上限としており, 費用損 失に関する評価関数を定式化することで, 全数 (1〜120 枚) 探索を行っても数分で費用損失を最小に する作業指示書枚数を見つけることが可能となる.

費用損失に関する評価関数は, 上記 Step 1 5 で求 めた基準加工数 $S^{d e c}$ と各作業間隔 $F_{i}$ に対し, $\left[F_{i} /\right.$ $\left.S^{d e c}\right]$ 以下で, かつ, 作業指示書枚数の約数の最大值を $K_{i}^{\text {dec }}$ として,

$$
\begin{aligned}
\text { 評価関数 } & =\frac{\sum^{W}\left\{C_{i} \times\left(F_{i}-K_{i}^{d e c} \times S^{d e c}\right) / F_{i} / K_{i}^{d e c}\right\}}{S^{d e c}} \\
& \times\left(1+\alpha \frac{N}{120}\right) \ldots \ldots \ldots \ldots \ldots \ldots \ldots \cdots \cdots \cdots \cdots \cdots \cdots \cdots \cdots \cdots(6)
\end{aligned}
$$

と定義した。ここで， $\alpha$ は 0 1の値をとる係数であ り, ペナルティ項の寄与度合を調整するために用い

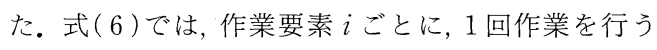
際に必要となる費用 (工具交換作業の場合は, 工具 1 本の費用) $C_{i}$ に, $\left(F_{i}-K_{i}^{d e c} \times S^{d e c}\right) / F_{i}$, すなわち, 可 能な最大間隔に対するむだにする間隔の割合を乗じて 1 回の作業でむだにする損失額を算出した後に，実際 の作業間隔 $K_{i}^{d e c} \times S^{d e c}$ で割ることで製品 1 個当たり の損失額とし, その合計を評価值としている.また, ほとんど同じ損失額ならば作業指示書枚数は少ないほ うが管理上容易になるため, 式 (6) 中にペナルティ項 を追加した～$\alpha$ はペナルティ項の寄与度であり, 経験 上 0.2 をデフォルトとしたが，ユーザが自由に変更す ることも可能とした。 上記式 (6)を 1～120までのす べての作業指示書枚数の候補值に対し計算すること 
で, 作業指示書枚数を考慮しながら, 費用損失額が小 さくなるような作業指示書枚数を得ることができる.

\section{6. 平準化スケジュール作成実験}

本システムを機械加工ラインの刃具交換作業を平準 化スケジューリングへ適用した事例を図 1,2 に示す。 ここで, 刃具本数 200 , 作業指示書枚数 60 である. 図 1 と図 2 は作業指示書番号を横軸に表し, 各作業指示 書で行う刃具交換作業時間の合計を縦軸に表してい る.図 1 が平準化スケジューリングを行う前の初期状
態(すべての $p_{k}$ が 1)であり, 図 2 が平準化スケジュ ーリングを行った結果である。ほぼ，すべての作業指 示書の作業時間がその平均時間から $\pm 8 \%$ 範囲内に収 まった。なお，計算時間はPentium II $450 \mathrm{MHz}$, メ モリ $256 \mathrm{MB}$ のパーソナルコンピュータで, 1 分ほど であり，工場併設の低スペックのパーソナルコンピュ 一夕上でも，実運用上，支障がない時間であった。他 のデータを用いた実験においても，作業要素数と作業 指示書枚数に比例して計算時間が増加する傾向にある が，実用上，問題がない時間で計算が終了した。

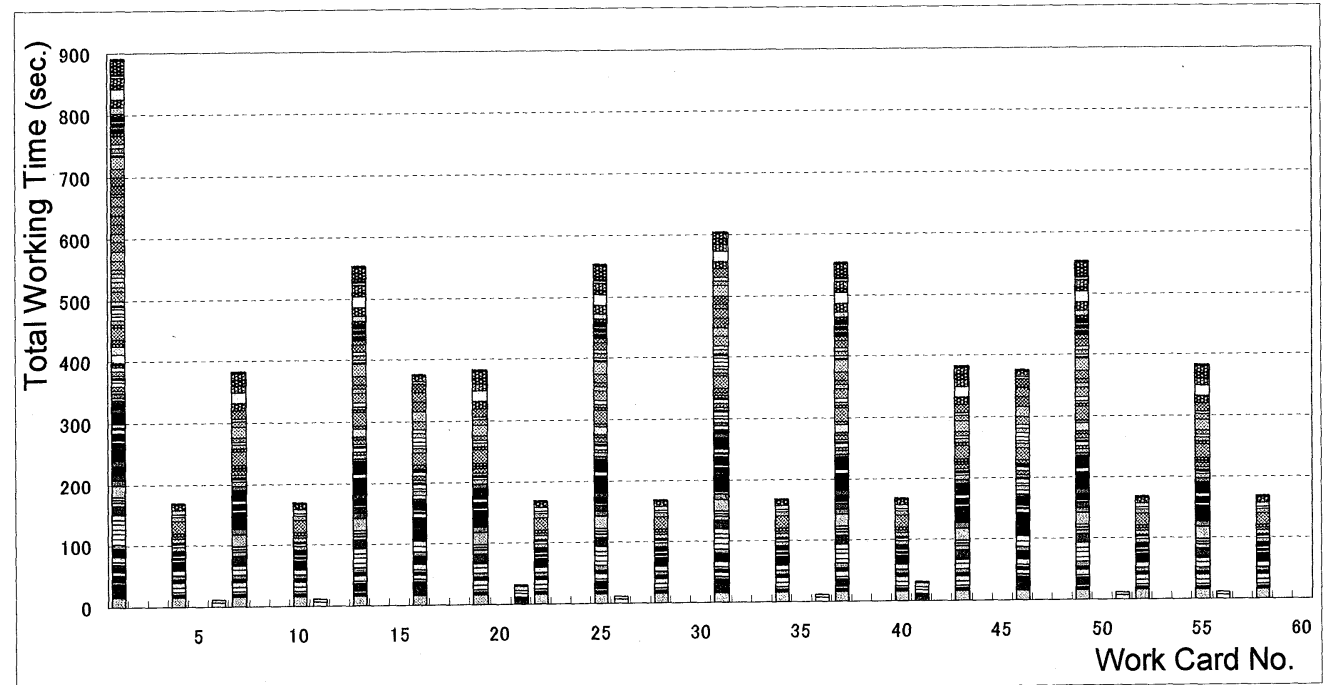

Fig. 1 An example of the test case (before)

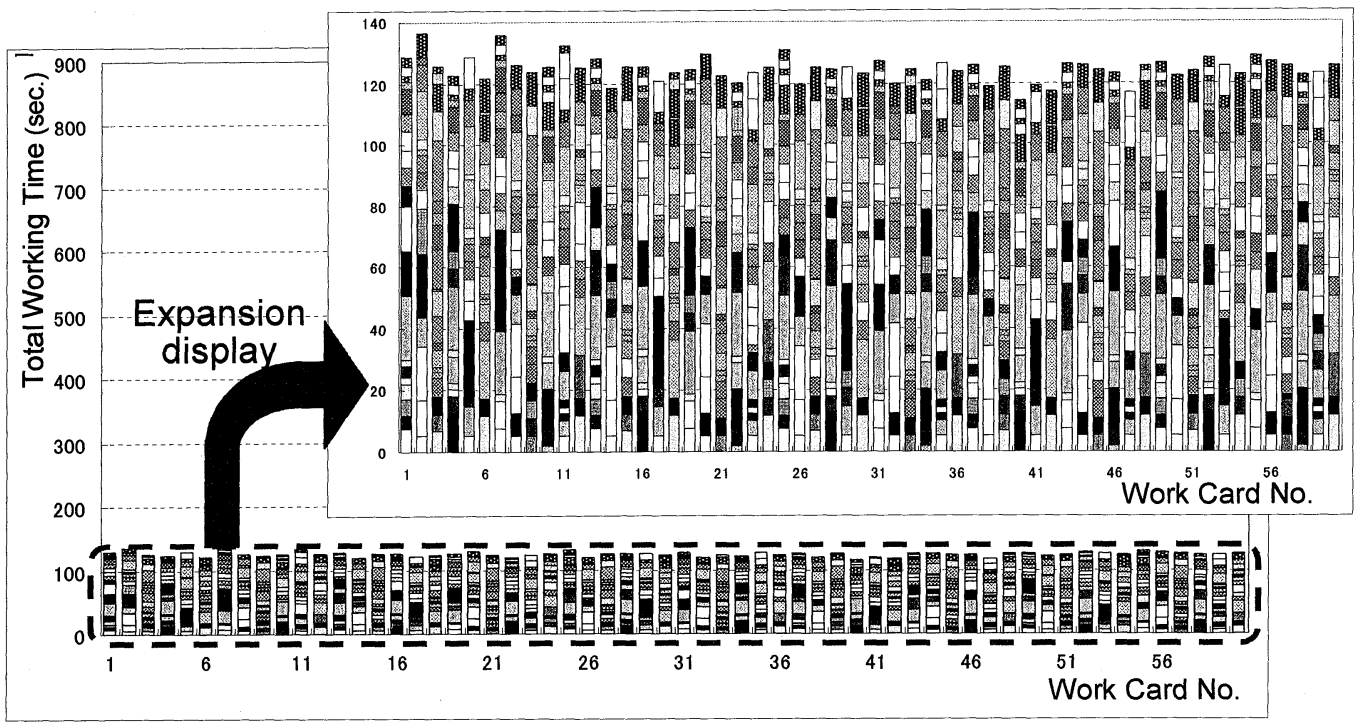

Fig. 2 The result of the test case (after scheduling) 
本システムで生成したスケジュールの良否を判定す ベく,いくつかの事例の入力データと平準化スケジュ ーリング結果(図 3 に例示) とその詳細情報を実際の工 場のスケジュール作成担当者数名に提示し, 本システ ムの結果より良いスケジュールを作成できるかを確か めさせた. その結果, 協力いただいたすべての担当者 から, 本手法の結果が最良である旨の回答を得ること ができた，そのことから，本システムが実用上，有効 であることを確認した。

\section{7. まとめと今後}

間接作業平準化方式は，生産システム内に含まれる さまざまな間接作業を平準化し，作業指示書へ割付け ることで，あたかも定常作業であるかのようにでき る.その結果, 作業者のスキルによらず, 工数低減だ けでなく作業員数を最少化することができる. 本方式 を効果的に運用するために，作業間隔の拡大等の力イ ゼン活動や, 生産比率変更に柔軟に再スケジューリン グできないという本方式の弱点を補うための平準化ス ケジューリングを自動で行うアルゴリズムを開発し た。また，本システムを初心者でも簡単に利用できる ように，本システムへの入力条件を見つけるための七
ユーリスティックスを取り入れたアルゴリズムも併わ せて開発した。

本システムは実運用向けに開発してきており，すで に実績を蓄えつつある。

今後は本システムを生産システムシミュレーション とリンクさせることで,

・ボトルネックを考慮した間接作業運用方法の検討

・故障復旧作業を考慮した作業指示書内の作業順決定 方法の検討

- 本方式の効果予測, 入力条件の事前評価

・減産時の作業工数削減方法の決定 (どれだけ設備を 止めても大丈夫か)

などの研究への展開が可能となると考えられる.

また，本システムにおいては，作業負荷を作業時間 と等価とみなすことで, 時間軸上での作業負荷の平準 化を行ってきたが，今後は，身体負荷に相当するウェ イトをかけた時間に変換し，また，身体負荷の大きい 作業を連続させないという制約条件を組込むことで, 身体的負荷の平準化も含めたスケジューリングシステ ムへ発展させていくことを検討する予定である。ま た, 生産システムの一部を一時停止させるような間接 作業を含む場合には, 生産システムの生産能力への影

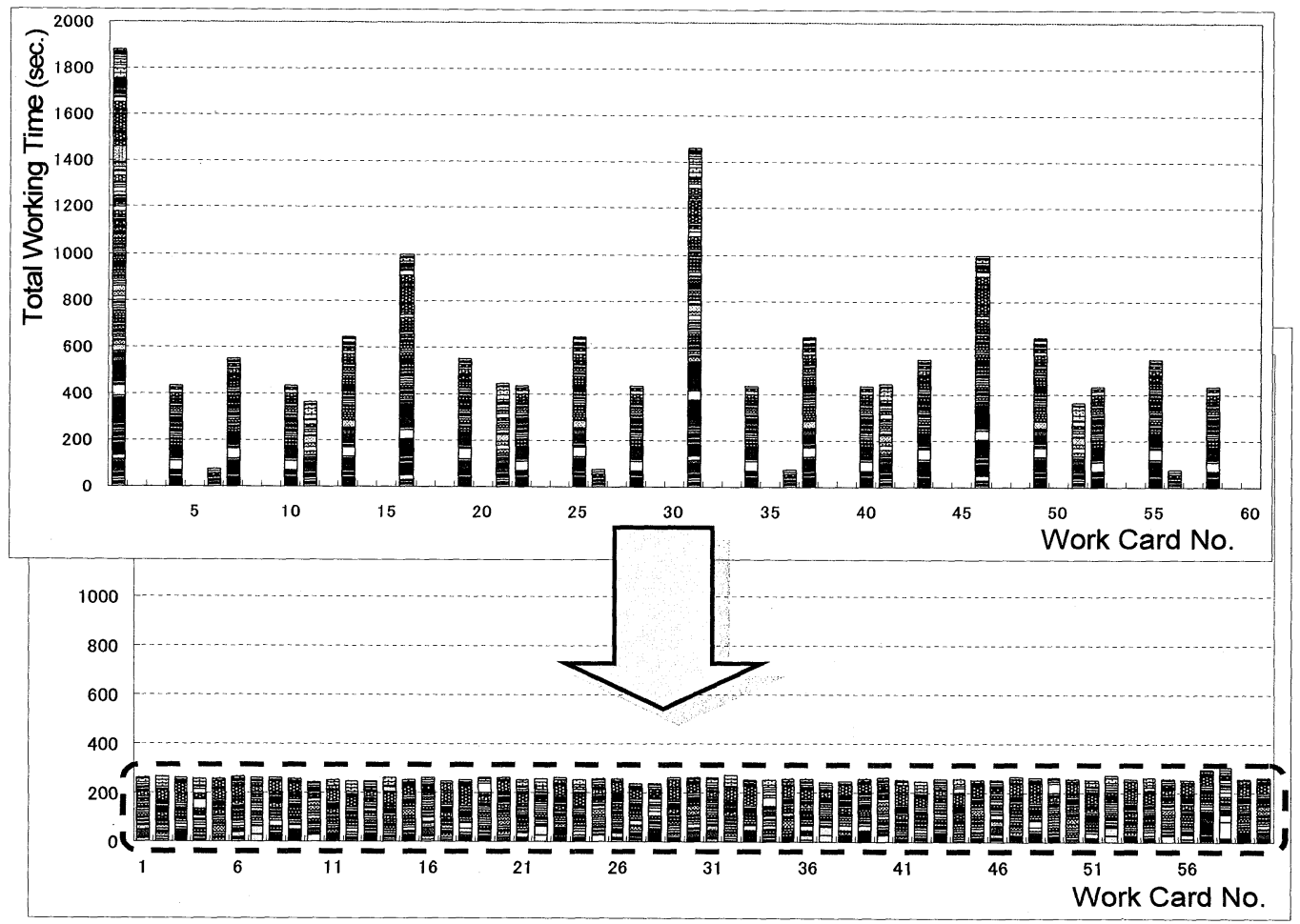

Fig. 3 The result of another test case 
響の最小化という観点から最適化し, 生産システムシ ミュレーションで確認し, 場合によっては変更を促す ように発展させていく予定である.

本研究を進めるに当たり, 多方面からの有益なご意 見やご指導をいただいたトヨ夕自動車(株)の関連部 署・関連工場の皆様に心よりお礼申し上げる.また, 本研究究の最中, つねにご指導や協力をいただいた (株) 豊田中央研究所の数理情報研究室メンバー，およ び, 論文執筆に際し稂切丁寧なご指導をいただいた東 京大学の木村文彦教授に心よりお礼申し上げる.

\section{文献}

(1) Ishibashi, M. et al., A Controlling Method in an Automobile Part Plant (in Japanese), DENSO Technical Review, Vol. 9, No. 1 (2004), pp. 133-138.

(2) Kuroda, M. and Muramatsu, K., Production Scheduling, (2002), pp. 164-232, Asakura Publishing Co., Ltd.
(3) Shimoda, Y. and Sakurai, F., Statistical Tool Replacement Procedures for Automatic Machining Centers (in Japanese), Journal of Japan Industrial Management Association, Vol. 45, No. 6 (1995), pp. 555-561.

(4) La Commare, U. et al., Optimum Tool Replacement Policies with Penalty Cost for Unforeseen Tool Failure, International Journal of Machining Tool Design Research, Vol. 23, No. 4 (1983), pp. 237-243.

(5) Li, L. X. and Benton, W.C., Performance Measurement Criteria in Health Care Organization, Review and future research directions, European Journal of Operational Research, (1996), pp. 449-468.

(6) Ikegami, A. et al., Nurse Scheduling Problem in Japan (in Japanese), Journal of the Operations Research Society of Japan, Vol. 41 (1996), pp. 436-442.

(7) Carpara, A. et al., A heuristic method for the Set Covering problem, Operations Research, Vol. 47 (1999), pp. 730-743.

(8) Yoshikawa, M., Automatic Solver for Class/Teacher/ Room Timetable (in Japanese), Joumal of the Operations Research Society of Japan, Vol. 46 (2001), pp. 461468. 